\title{
Risk Factors in a Process of Gas Supply Pipeline Construcion
}

\author{
Sebastian Kosmalski ${ }^{1, *}$ and Józef Myrczek $^{2}$ \\ ${ }^{1}$ STALPROFIL S.A. Branch in Zabrze, Magazynowa 6 Street, 41-807 Zabrze, Poland, s.kosmalski@zrugzabrze.pl \\ ${ }^{2}$ University of Bielsko-Biala, Faculty of Materials, Civil and Environmental Engineering, Willowa 2 Street, 43-309 Bielsko-Biała, \\ Poland, jmyrczek@ath.bielsko.pl
}

\begin{abstract}
The paper applies to the risk management in the specialized construction by the example of construction of a high-pressure gas supply pipeline. The specific character of the construction project has an impact on the scope and types of risks which may occur and adversely affect the outcome of the project. The paper aims to indicate the groups of technological tasks which need to be carried out when constructing a gas supply pipeline, the associated factor risks and the quality control method as a tool of mitigating the level of risk.
\end{abstract}

\section{Introduction}

Investing in a gas supply infrastructure is a costly, complex and multi-step undertaking. Since such infrastructure is a strategic component of a national energy supply system, which is designed to provide energy supplies for production and service processes, for the needs of collective and individual heat supplies, its reliability and uninterrupted operation must be ensured. Every participant of an investment process (an investor, a designer and a contractor) has to be fully aware of the requirements and bear liability for the tasks they have undertaken to perform. Therefore, appropriate supervision and control become a key element of a construction process with the view to acknowledging and ensuring that a given facility will be built in compliance with the construction law, the conditions specified in a building permit, the applicable regulations and standards as well as the investor's demands.

The character of a gas supply pipeline construction project has an impact on the scope and types of risks which may occur and adversely affect the outcome of the project. The paper aims to indicate the groups of technological tasks which need to be carried out when constructing a gas supply pipeline, the associated risks and any ways in which risks may be mitigated using the right quality control methods. The study is based on the actual historical data (documentation of the gas pipeline constructions in the period of 2012-2017), from the polish STALPROFIL S.A. (joint stock company) group experts' information (employees) and the literature on the subject. The methods of risk analysis in the construction had been based on the theoretical approach described in $[1,2]$. The risks in the pipeline construction projects may be of different origin, including: design risk, management risk, construction risk, subcontractor risk, political/governance risk, economical/financial risk, owner generated risk, material risk and equipment generated risk. However, in this paper we concentrate on construction risk. The construction risk remains in relation with the majority of other listed above risks [3].

\section{Risk factors and the specific groups of technological tasks in a gas supply pipeline construction process}

Construction activities related to linear facilities are exposed to a variety of risks and hazards, the occurrence of which may significantly distort the process and lead to e.g. delays, cost overruns and, in some extreme cases, discontinuation of a project or a failure to complete a given task.

Making a decision on the participation in a tender or on the acceptance of a contract, a party involved should be fully aware of any unfavourable events which may occur and should be able identify these in an effective way. Such unfavourable phenomena or risks of a given project should be carefully and meticulously specified and documented. An analysis of risk factors, the determination of preventive actions, the assignment of personal responsibility and the scheduling of periodic or continuous monitoring of both the formerly identified and the new risks, may help us find the right directions for actions, mitigate these risks and protect our operations from the consequences of such undesirable events. All these efforts, when conducted in a planned manner, will create a system to implement a risk management policy.

The risk analysis for the construction of a gas supply pipeline shows that the process is highly complex and covers many stages, which can also be translated into the scope and extent of risks that may have a negative impact on the outcome - the aim of the project. In the study 16 groups of the technological tasks which are performed when producing a gas supply was taking into

Corresponding author: jmyrczek@ath.bielsko.pl 
consideration. The study identifies 116 risks which are specific to the construction of gas supply pipelines (Table 1). The risk factors, which have been established, are ranked according to the weights assigned to them. The weights has been estimated as the normalized (between 0 and 1) result of multiplication of the probability of occurrence (from the historical data) and the cost. This gives an overall picture of what risks may be considered critical, i.e. which risks are expected to have the biggest impact on the construction process failure or success. The risks were divided into three groups: high risks (risk weight 0,200-1,00), moderate risks ( risk weight $0,050-0,200$ ) and low risk (risk weight less than 0,050). Then the risk factors were assigned to groups of technological tasks (Table 2). The most vulnerable technological tasks are: welding, connections in trenchless technology technological facilities - gas units. The failure in these groups of technological tasks can be easily detected by standard quality control methods (e.g. x-ray inspection). However the other risk factors can not be neglected as the risk occurrence is usually described as critical in pipeline industry.

Table 1. Risk factors and their weights

\begin{tabular}{|c|c|c|}
\hline No. & Risk factor & Risk weight \\
\hline 1 & Incorrect placement of pipes for ramming and borings & 0.560 \\
\hline 2 & Incorrect installation of a supply pipe in a protective pipe & 0.560 \\
\hline 3 & Failure to achieve the required resistance of a connection or jacking pipe after drawing & 0.560 \\
\hline 4 & Incorrect production of a weld - no acceptance & 0.400 \\
\hline 5 & Failure to meet insulation parameters of joints & 0.400 \\
\hline 6 & Leaving blocks, debris, stones, roots etc. in a trench & 0.400 \\
\hline 7 & Incorrect insulation of protective pipe terminals in a pipeline & 0.400 \\
\hline 8 & HDD boring - diversion from a planned route & 0.400 \\
\hline 9 & $\begin{array}{l}\text { Incorrect testing of an insulation layer for leakage, failure to find the location of a } \\
\text { defect using DCVG survey }\end{array}$ & 0.400 \\
\hline 10 & Incompliant quality documentation (for acceptance tests) & 0.400 \\
\hline 11 & $\begin{array}{l}\text { Failure to restore the land to its original condition (when handing the land over to the } \\
\text { owner) }\end{array}$ & 0.280 \\
\hline 12 & Defective joints, exceeding the limit specified in the tender & 0.240 \\
\hline 13 & Welders and/or welding equipment operators without required authorisations & 0.240 \\
\hline 14 & Welding conducted by the Ordering Party's unauthorised welders and operators & 0.240 \\
\hline 15 & No required authorization held by a Non-destructive Testing Laboratory & 0.240 \\
\hline 16 & No non-destructive testing of joints (RT, UT, MT, PT) & 0.240 \\
\hline 17 & Failure to meet insulation requirements for fittings & 0.240 \\
\hline 18 & $\begin{array}{l}\text { Failure to perform (or incorrect performance) of insulation testing for joints using a } \\
\text { defectoscope }\end{array}$ & 0.240 \\
\hline 19 & $\begin{array}{l}\text { Failure to perform (or incorrect performance) of pipe tightness tests with a } \\
\text { defectoscope before placement of a pipeline in a trench }\end{array}$ & 0.240 \\
\hline 20 & $\begin{array}{l}\text { Failure to perform (or incorrect performance) of an insulation tightness test for } \\
\text { fixtures with a defectoscope }\end{array}$ & 0.240 \\
\hline 21 & Failure to repair damaged insulation & 0.240 \\
\hline 22 & $\begin{array}{l}\text { Failure to perform (or incorrect performance) of insulation testing on separated (zero } \\
\text { defect) sections }\end{array}$ & 0.240 \\
\hline 23 & No correct protection of trenches & 0.240 \\
\hline 24 & Incorrect placement of a gas supply pipeline in a trench (axis and cover) & 0.240 \\
\hline 25 & Filling trenches with blocks, debris, stones, roots etc. & 0.240 \\
\hline 26 & HDD boring - a supply pipeline stuck under the ground & 0.240 \\
\hline 27 & Inaccurate tightening of screws on a flange & 0.240 \\
\hline 28 & Pressure drop in tightness or fatigue testing & 0.240 \\
\hline 29 & Failure to introduce changes to design documents & 0.240 \\
\hline
\end{tabular}




\begin{tabular}{|c|c|c|}
\hline 30 & Changes not accepted by a designer or a construction site inspector & 0.240 \\
\hline 31 & Lack of pipeline tightness e.g. in fixtures or flange connections & 0.240 \\
\hline 32 & Unreliability of devices used during commissioning & 0.240 \\
\hline 33 & Incorrect accounting for investor supplied pipes and fixtures & 0.240 \\
\hline 34 & Failure to obtain an operating permit & 0.240 \\
\hline 35 & $\begin{array}{l}\text { Failure to obtain a decision from the Office of Technical Inspection (UDT) with an } \\
\text { operating permit }\end{array}$ & 0.240 \\
\hline 36 & Incorrect assembly and placement of sinkers & 0.200 \\
\hline 37 & No sinkers placed on geotextile & 0.200 \\
\hline 38 & $\begin{array}{l}\text { Incorrect placement of a pipeline at intersection with another infrastructure (vertical } \\
\text { distance) }\end{array}$ & 0.200 \\
\hline 39 & Failure to perform (or incorrect performance) of soil compaction & 0.200 \\
\hline 40 & Incorrect repair or patency of drains and melioration systems (ditches) & 0.200 \\
\hline 41 & HDD boring - hydraulic breakthrough of drilling fluids & 0.200 \\
\hline 42 & Collision of a boring with an underground infrastructure & 0.200 \\
\hline 43 & Leaks in insulation layers of fittings & 0.200 \\
\hline 44 & Dirt inside the pipeline & 0.200 \\
\hline 45 & Incorrect gas pipeline manual - no approval from UDT and/or the Ordering Party & 0.200 \\
\hline 46 & No Welding Procedure Specification (WPS) for a given type of connection & 0.120 \\
\hline 47 & Failure to submit results to WRB in a timely manner & 0.120 \\
\hline 48 & No monitoring of welding parameters for joints & 0.120 \\
\hline 49 & Too shallow/deep trench & 0.120 \\
\hline 50 & Uneven shaping of a trench bottom & 0.120 \\
\hline 51 & No sand bedding & 0.120 \\
\hline 52 & No sand shading & 0.120 \\
\hline 53 & No sand backfill & 0.120 \\
\hline 54 & Incorrect filling of space between pipes with insulation mass (if required) & 0.120 \\
\hline 55 & Planned pressure testing not agreed on by UDT and the Ordering Party & 0.120 \\
\hline 56 & Inability to dry a pipeline to the required dew point & 0.120 \\
\hline 57 & Incorrect production of cathodic protection connections & 0.120 \\
\hline 58 & $\begin{array}{l}\text { Failure to perform periodic measurements of pipeline resistance between } \mathrm{P} \text { and } \mathrm{S} \\
\text { points }\end{array}$ & 0.120 \\
\hline 59 & Correctness of an anode ground bed & 0.120 \\
\hline 60 & Correctness of stationary reference electrodes & 0.120 \\
\hline 61 & Placement of cables in a trench incompliant with the design & 0.120 \\
\hline 62 & Insufficient separation of electric devices from pipelines & 0.120 \\
\hline 63 & $\begin{array}{l}\text { No control over welding of fixtures with a pipe (e.g. measurement of welding } \\
\text { temperature) }\end{array}$ & 0.120 \\
\hline 64 & Planned pressure tests not agreed on with UDT and the Ordering Party & 0.120 \\
\hline 65 & Failure to perform (or incorrect performance) of soil compaction & 0.120 \\
\hline 66 & Incorrect Quality Assurance Scheme (if required) & 0.100 \\
\hline 67 & Incorrect Control and Testing Plan (if required) & 0.100 \\
\hline 68 & Incorrect Health and Safety Scheme & 0.100 \\
\hline 69 & Incorrect Environmental Protection Scheme & 0.100 \\
\hline 70 & Incorrect procedure specifications for performance of selected tasks & 0.100 \\
\hline 71 & A construction site inspector's refusal to approve the material to be built into & 0.080 \\
\hline
\end{tabular}




\begin{tabular}{|c|c|c|}
\hline 72 & $\begin{array}{l}\text { Building in of the materials which has not been approved by a construction site } \\
\text { inspector }\end{array}$ & 0.080 \\
\hline 73 & No required and approved welding technologies & 0.080 \\
\hline 74 & $\begin{array}{l}\text { No authorisations held by people who perform non-destructive testing in a given } \\
\text { method }\end{array}$ & 0.080 \\
\hline 75 & No visual testing of joints - VT (required $100 \%$ ) & 0.080 \\
\hline 76 & $\begin{array}{l}\text { Failure to perform (or incorrect performance) of insulation testing after the pipeline is } \\
\text { placed and backfilled }\end{array}$ & 0.080 \\
\hline 77 & $\begin{array}{c}\text { Incorrect use of placement technology (layout of girders, deflection, straps, } \\
\text { equipment) }\end{array}$ & 0.080 \\
\hline 78 & Pressure drop in tightness or fatigue testing of a pipeline & 0.080 \\
\hline 79 & $\begin{array}{l}\text { No required and approved technologies for cathodic protection connections with a } \\
\text { pipeline }\end{array}$ & 0.080 \\
\hline 80 & Incorrect configuration of telemetric and facility control data & 0.060 \\
\hline 81 & Incorrect readings of pressure transmitters & 0.060 \\
\hline 82 & No mechanical response to start-up and verification of valve and bolt automation & 0.060 \\
\hline 83 & Incorrect placement of fixtures on foundations & 0.060 \\
\hline 84 & Careless placement of paint layer on steel above ground components & 0.060 \\
\hline 85 & Imprecise laying of foundations (trench control) & 0.060 \\
\hline 86 & $\begin{array}{c}\text { Delays in supplies of materials (e.g. pipes, steel fittings, additional materials for } \\
\text { welding, insulation materials) }\end{array}$ & 0.040 \\
\hline 87 & Materials incompliant with an order & 0.040 \\
\hline 88 & $\begin{array}{l}\text { Incorrect dimensions of components, poor condition of insulation or incorrect } \\
\text { operation of devices/fixtures from own purchases }\end{array}$ & 0.040 \\
\hline 89 & Failure to provide quality documents together with a consignment & 0.040 \\
\hline 90 & Incomplete material documentations & 0.040 \\
\hline 91 & No welding supervision with authorisations, as per PN-EN 14731 & 0.040 \\
\hline 92 & Incorrectly prepared joints for welding & 0.040 \\
\hline 93 & Incorrect lamination of pipes or welds & 0.040 \\
\hline 94 & $\begin{array}{l}\text { Failure to perform the right number ( } 1 \text { per } 300 \text { welds) of adherence tests for insulation } \\
\text { on pipes and welds }\end{array}$ & 0.030 \\
\hline 95 & Unreliable assembly and stability of fencing & 0.030 \\
\hline 96 & Failure to perform (or incorrect performance) of marking on welds & 0.025 \\
\hline 97 & The area not checked by explosives engineers & 0.020 \\
\hline 98 & No archeologic survey in the earth work area & 0.020 \\
\hline 99 & Incorrect welding plan for a pipeline & 0.020 \\
\hline 100 & No testing of cut pipe terminals for delayering & 0.020 \\
\hline 101 & $\begin{array}{l}\text { Insufficient capacity of pumps - difficulties in filling a pipeline with water and getting } \\
\text { the right pressure }\end{array}$ & 0.020 \\
\hline 102 & No or poor GSM signal & 0.020 \\
\hline 103 & Inability to dry a pipeline to the required dew point & 0.020 \\
\hline 104 & No inspection log books (for pressure devices in facilities) obtained & 0.020 \\
\hline 105 & No notification to the owner about the entry to their land (construction site) & 0.010 \\
\hline 106 & Incorrect operation of fixtures after testing & 0.010 \\
\hline 107 & Use of concrete mixture with is incompliant with a specification & 0.010 \\
\hline
\end{tabular}




\begin{tabular}{|c|c|c|}
\hline 108 & $\begin{array}{c}\text { Waste processing areas incompliant with a specification (e.g. subbase thickness, } \\
\text { curbs) }\end{array}$ & 0.010 \\
\hline 109 & Access roads incompliant with a specification & 0.010 \\
\hline 110 & Failure to meet final acceptance requirements for a pipeline & 0.010 \\
\hline 111 & Incorrect pre-project environmental assessment report & 0.005 \\
\hline 112 & Incorrect angle of an arc & 0.005 \\
\hline 113 & Incorrect roundness of a pile at a bending point & 0.005 \\
\hline 114 & Incorrect thickness of a wall and condition of insulation after bending & 0.005 \\
\hline 115 & Incomplete testing of welds & 0.005 \\
\hline 116 & Incorrect marking of a pipeline route with posts & 0.005 \\
\hline
\end{tabular}

Table 2. Risks in specific groups of technological tasks.

\begin{tabular}{|c|c|c|c|c|c|c|}
\hline No & Group of technological tasks & $\begin{array}{l}\text { No. of low } \\
\text { risks }\end{array}$ & $\begin{array}{c}\text { No. of } \\
\text { moderate risks }\end{array}$ & $\begin{array}{l}\text { No. of high } \\
\text { risks }\end{array}$ & \begin{tabular}{|c|} 
No. of risks \\
per a \\
technological \\
activity \\
\end{tabular} & $\begin{array}{l}\text { Percentage } \\
\text { share in } \\
\text { total }\end{array}$ \\
\hline 1 & Preparing quality documentation & 0 & 5 & 0 & 5 & $4.31 \%$ \\
\hline 2 & Commencement of work & 4 & 0 & 0 & 4 & $3.45 \%$ \\
\hline 3 & Purchase of materials & 5 & 2 & 0 & 7 & $6.03 \%$ \\
\hline 4 & Cold bending of steel tubes & 3 & 0 & 0 & 3 & $2.59 \%$ \\
\hline 5 & Welding & 6 & 6 & 6 & 18 & $15.52 \%$ \\
\hline 6 & Insulation & 1 & 1 & 7 & 9 & $7.76 \%$ \\
\hline 7 & Digging of trenches & 0 & 3 & 2 & 5 & $4.31 \%$ \\
\hline 8 & Placing of a pipeline & 0 & 2 & 4 & 6 & $5.17 \%$ \\
\hline 9 & $\begin{array}{l}\text { Burying of the pipeline and land } \\
\text { reconstruction }\end{array}$ & 1 & 1 & 4 & 6 & $5.17 \%$ \\
\hline 10 & $\begin{array}{c}\text { Connections in trenchless } \\
\text { technology }\end{array}$ & 1 & 1 & 8 & 10 & $8.62 \%$ \\
\hline 11 & Pressure tests & 1 & 3 & 0 & 4 & $3.45 \%$ \\
\hline 12 & Installation of cathode protection & 0 & 5 & 1 & 6 & $5.17 \%$ \\
\hline 13 & Technological facilities - gas units & 7 & 11 & 4 & 22 & $18.97 \%$ \\
\hline 14 & Technical acceptance & 0 & 0 & 3 & 3 & $2.59 \%$ \\
\hline 15 & Filing with gas and start-up & 0 & 0 & 2 & 2 & $1.72 \%$ \\
\hline 16 & $\begin{array}{l}\text { Final acceptance and handover for } \\
\text { operation }\end{array}$ & 2 & 0 & 4 & 6 & $5.17 \%$ \\
\hline & Total & 31 & 40 & 45 & 116 & $100 \%$ \\
\hline \multicolumn{2}{|r|}{ Percentage share in the risk group } & $26.72 \%$ & $34.49 \%$ & $38.79 \%$ & $100 \%$ & \\
\hline
\end{tabular}

\section{Conclusion}

The failure of the high-pressure gas pipeline would be extremely dangerous for both people, civil engineering constructions (including buildings), and environment. Therefore the use of any method which will diminish the probability of occurrence of such an event is necessary. The process of the construction of the gas pipeline is very complicated and many risk factors can occur. The critical factors can materialise at different stages of the construction process. Therefore the in-process risk management is a proper tool in these cases. Additionally, such an approach is used widely in infrastructural construction projects [e.g. 4]. Having identified the main risk factors in the pipeline construction process (as stated above) one can try to manage it. The main tool of risk management in the industry is quality control (eg. [5]). 
The purpose of quality control is to check and assess, in an independent manner, the compliance and the progress of a construction process in order to ensure that the planned work quality is met. A contractor which builds the given gas supply pipeline is responsible for the correct application of technologies and for the quality of materials to be built in at every stage throughout a project delivery process, assuming the risk of any potential failure to perform or duly perform. That is why it is so vital to have well-qualified staff, whose members are well-organised and will carry out control activities, as set out in the project and tender documents, resulting from the legal status and required by the investor. In case of a highly complex construction project, the contractor may draw on their subcontractor's expertise and experience from conducting similar assignments, also in the area of quality control. Quality control staff should act within an established system of control, be provided with the necessary documents, equipment and measuring devices to enable them to evaluate the quality of work. The contractor, in the course of the construction process, should carry out all tests, examinations and checks needed to verify the compliance of the work performed with the requirements specified in the technical design, the technical terms and conditions of delivery and acceptance, all the applicable standards and the investor's guidelines [6].

When it comes to highly complex projects, in particular the ones in which the occurring risks may negatively affect human health, lives, the natural environment or result in substantial financial losses, it would definitely be advisable to implement in-process control as a tool for monitoring and mitigating risks. Such procedures are commonly applied in the pharmaceutical industry [7, 8]. They assume that the next stage of a project may not be started until the previous one has been reviewed in terms of its compliance with the quality targets established for this phase. Owing to in-process quality control the planned quality of project deliverables can be ensured and the entire process can be controlled. To be sure that such tasks are performed in a reliable manner Quality Assurance staff and production workers need to be given autonomy (independence). Such an approach tends to be adopted in the construction business [9]. It is part of a total quality control system and it is used especially in cases when no faulty component may be allowed to appear throughout the process. Although it is impossible to expect any construction process to run without any possible faults, quality may be significantly boosted and potential risks can be considerably limited and prevented from occurrence $[10,11]$.

\section{References}

1. Teixeira J. C., Kulejewski J., Krzemiński M., Zawistowski J., „Zarządzanie ryzykiem w budownictwie", Biblioteka Menedżerów Budownictwa, Guimaraes, Warszawa 2011
2. Tworek P., „Reakcja na ryzyko w działalności przedsiębiorstwa budowlano-montażowego", Wydawnictwo Difin, Warszawa 2013

3. Zabel N.Y., Georg M.E., Ibrahim M.E., Developing a dynamic risk map (DRM) for pipeline construction projects in the Middle-East, WIT Transaction on Information and Communication Technologie vol. 44, 2012 WIT Press (on-line release www.witpress.com)

4. Wang S. Q. et al., Risk management framework for construction projects in developing countries, Construction Management and Economics, 22, 237252 (2004).

5. Pipeline Construction : Quality Issues and Solution Action Plans 2012, The INGAA Foundation In., (ingaa.org)

6. Howarth T., Greenwood D., Construction Quality Management: Principles and Practise, second edition, (Routledge 2017)

7. Abhay Verma, Pranshu Tangri et al., „In proces quality control : A review, International Journal of Industrial Pharmacy and BioSciences 1(1); (MayJune 2014)

8. Gausepohl C., Mukherji P., GMP Manual (Up07) CMaas\&Peither AG - GMP Publishing (https: //www.gmp-publishing.com/media/files/logfiles/ Reading_Sample_11.I-In-process_control.pdf 25.03.2018)

9. Hendrickson C., Project Management for Construction, Prentice Hall 2008 (www edition : https:///www.cmu.edu/cee/projects/PMbook/index.h tml 25.03.2018

10. Tworek P., Project risk management in the Polish construction industry - selected theoretical and practical aspects . in : Strategic Management and its Support by Information Systems. Edited by J. Kaluza. VŚB - Technicka Univerzita Ostrava, Ostrava, ( 2009 )

11. Raczkowski K., Tworek P., What does risk management in an economy really means? In : Raczkowski K. (ed.) : Risk Management in Public Administration, (Palgrave Macmillan, London-New York 2017) 